усовершенствоваться, как предложения различных киноуслуг - должна ориентироваться на выполнение социально-культурной функции в киноиндустрии.

$$
* * *
$$

1. Чумиков А.Н., Реклама и связи с общественностью: Имидж, репутация, бренд. - М.: Аспект Пресс, 2016. 129 c.

2. Эпштейн Э. Экономика Голливуда, Заработок киностудий. - М.: Альпина Паблишерз, 2018. - 212 c.

3. Aronson, M.The Public Relations Writer's Handbook: The Digital Age / M. Aronson, D. Spetner, C. Ames. - John Wiley \& Sons, 2010. - 368 p.

4. Cartwright, S. Pre-Production Planning for Video, Film, and Multimedia / Steve Cartwright. - Boca Raton: CRC Press, 2012.- 229 p.

5. $\quad$ Egan, J. Marketing Communications / John Egan. - Thousand Oaks: SAGE, 2014. - 440 p.

6. Eve Light Honthaner. The Complete Film Production Handbook / Eve Light Honthaner. - London: Taylor \& Francis, 2013. - $496 \mathrm{p}$.

7. к/ф "Движение вверх" [Электронный ресурс] // КиноПоиск. Все фильмы планеты. - Режим доступа: https://www.kinopoisk.ru/film/840817 - (Дата обращения: 05.08.2021).

8. $\quad$ к/ф "Почему он?" [Электронный ресурс] // КиноПоиск. Все фильмы планеты. - Режим доступа: https://kinopoisk.ru/film/930000/ord/rnd/rnd/1546859826 - (Дата обращения: 05.08.2021).

\title{
Самойлова М.П.
}

Рецепция античности: научные подходы прошлого и современности

ФГБОУ ВО «Нижегородский государственный лингвистический университет им. Н.А. Добролюбова»

(Россия, Нижний Новгород)

doi: 10.18411/trnio-09-2021-103

\section{Аннотация}

Статья посвящена проблематике рецепции античности в западной культуре. Анализируются подходы к рассмотрению феномена рецепции античного наследия в ХX веке и современности, анализируются причины рецепции, а также оценки этого процесса в концепциях ведущих ученых XX-XXI вв. Автор приходит к выводу о том, что освоение античного наследия становится попыткой адаптировать античную систему ценностей к современному обществу.

Ключевые слова: античное наследие, рецепция, рецептивная эстетика, межкультурная коммуникация.

\section{Abstract}

The article is devoted to the problems of reception of antiquity in Western culture. The author analyzes the approaches to the consideration of the phenomenon of reception of ancient heritage in the twentieth century and the present, analyzes the causes of reception, as well as the evaluation of this process in the concepts of leading scientists of the XX-XXI centuries. The author comes to the conclusion that the development of the ancient heritage becomes an attempt to adapt the ancient system of values to modern society.

Keywords: ancient heritage, reception, receptive aesthetics, intercultural communication.

Рецепция античности - одна из главных тенденций в западной художественной культуре современности. Античная культура занимает ведущее место среди культур, оказавших влияние на культуру современных христианских цивилизаций. Древнегреческая цивилизация стала колыбелью демократии, в ней на новый качественный уровень было поднято понимание человека - творца самого себя и своей истории, зародился первый вариант гуманизма. Нравственные, художественные, политические и научные достижения античности стали причиной рецепции ее в последующих столетиях. Рецепция античности в той или иной мере была свойственна всем христианским культурам от Средневековья до современности. 
Термин «рецепция» в толковом словаре определяется как приспособление одним обществом культурных норм, возникших в другом. Д.Н. Ушаков в словарной статье делает отсылку к рецепции Римского права. [1.] Словарь Античности также отражает понятие «рецепция античности», делая акцент на то, что процесс заимствования античных идей, мотивов греко-римского наследия носил сознательный характер, данный процесс был социально обусловлен, т.е., надо понимать, вызван культурными потребностями заимствующей, принимающей стороны, и, что очень важно, элементы античности играли в новой культуре роль образца, идеала [2, с. 484].

Поскольку процесс рецепции подталкивается потребностями и процессами развития культуры принимающей стороны, заимствование культурных форм античности может проходить в области социальных институтов, культурных ценностей, морали, политических и иных норм. Источником заимствований могут также служить исторические личности античной эпохи, персонажи и события, античность в целом.

Исследование процесса рецепции начал выдающийся русский антиковед XX века, профессор Императорского Харьковского университета В.П. Бузескул. Он в ходе исследований историографии древнегреческой истории XIX века высказал мысль о том, что наука об античности постоянно изменяется под влиянием общественных настроений современности. Он был сторонником модернизации событий древней истории, полагая, что перед древними людьми стояли те же вопросы, что и перед современниками, люди древности жили обычными интересами близкими современным людям [3, с. 48-56].

Уже в 1920-х Бузескулом был выдвинут важный для понимания проблематики рецепции тезис: «отношение античного мира к современному мы можем рассматривать, не только имея в виду, как много первый дал второму, как античность отражается в современности, но и наоборот - как много в античном мире “современного", такого, что считается принадлежностью нашего времени» [4, с. 6].

В настоящей работе мы рассматриваем артефакты художественной культуры двух разных эпох - античной и современной, а именно произведения античных и современных авторов, предложивших собственную интерпретацию одного и того же мифа. Созданий произведений с использованием античного сюжета - есть один из способов усвоения и приспособления античных культурных форм авторами этих произведений (применительно к данной работе - наших современников), то есть вариант рецепции античности.

Беря за основу или ссылаясь на античный миф, получивший свою известность, благодаря древнегреческим драматургам, современные авторы высказывают свое, новое слово в отношении данного предмета (мифа), вступая, таким образом, во внутренний диалог с античными авторами, который становится зримым и внешним при условии доступности их произведений обществу. Подобный взгляд на процесс «общения» двух культур позволяет нам рассматривать рецепцию античности как диалог культур античности и современности через произведения искусства - этот путь рецепции можно назвать эстетической рецепцией.

О разделении всех видов рецепции, изучаемых в гуманитарных науках, на прагматические и эстетические пишет в своем исследовании современный российский ученый, интересующийся как античностью, так и современностью, Е.А. Чиглинцев [5, с. 14]. Прагматическая рецепция обозначает использование интеллектуальных наработок для решения насущных социальных задач, что, например, наблюдается в истории права и правовых институтов. Начиная со средних веков, многие правовые проблемы в ряде стран оптимально решались благодаря нормам римского права [6, с. 1245-1250]. Рецепцию античной философии в Средневековье можно также считать прагматичной: средневековая схоластика воспринимала неоплатонизм в более адекватной для христианской культуры форме, восточно-христианской рецепции [5, с. 11].

Эстетический вид рецепции относится к художественной культуре и изучается в литературоведении и искусствоведении. Эстетическая рецепция античности может иметь как пассивный характер (перевод и инсценировка античных произведений литературы), так и 
активный, которому можно отнести подражание или создание нового произведения на античную тему, переделка античных произведений на новый лад [2, с. 484].

Самый распространенный вариант рецепции античности в литературе - это перевод и интерпретация произведений античных авторов. Литературоведы часто обращаются к творчеству отдельных поэтов и писателей в поисках интерпретации ими сюжетов античной мифологии [6, с. 256]. В истории искусств большое внимание уделяется изучению античных реминисценций в изобразительном искусстве, скульптуре и архитектуре.

Опыт взаимодействия культур античности и современности нашел обобщение в теории межкультурной коммуникации и в теории рецептивной эстетики. Термин «рецептивная эстетика» был введен Х.Р. Яуссом в опубликованной в 1967 году научной работе. В основу его концепции был положен диалогический принцип, который предполагает взаимодействие между художественным произведением и его адресатом по модели разговора между людьми. В исторической протяженности рецепция художественного произведения субъектами разных культурно-исторических эпох проходит по-разному, значение и понимание художественного произведения все время меняется в зависимости от конкретной эпохи [7, с. 170].

В исследовании рецепции Х.Р. Яусс пытался понять, каким образом происходит «литературное общение» читателя-реципиента и автора, в ходе которого «незнакомое» становится понятным. Используя наработки структуралистов, Бахтина (диалогический метод), Гадамера (герменевтический метод), семиотический анализ, Х.Р. Яусс акцентировал внимание именно на восприятии произведения читателем или слушателем, изучении социокультурной ситуации, современной реципиенту, пытаясь преодолеть, таким образом, разделение литературы и истории, эстетического и исторического познания.

Герменевтический анализ, сама история интерпретаций событий и художественных произведений прошлого, по мнению Х.Р. Яусса, не только проливает свет на это прошлое, но и позволяет нам, людям поздней эпохи, открыть в объекте исследования множество смыслов, которые были непостижимы его современниками, то есть людьми прошедшей эпохи. При этом в качестве инструмента литературной герменевтики Х.Р. Яусс предлагает «кругозор» реципиента $[8$, p. 8$]$.

Под влиянием школы Х.P. Яусса рецепцию античности («classical reception») стали активно изучать англичане и американцы. Чарльз Мартингейл в 1993 году выдвинул идею адаптации теории рецепции к изучению классики [5, с. 14]. Англоязычные исследователи опираются так же на идеи структуралистов и постструктуралистов, используя для определения диалога современности и классики в литературных произведениях понятие «интертекстуальности» Ю. Кристевой [9, р. 4]. Англоязычные исследователи, таким образом, развивают идею Яусса о необходимости проводить исследование рецепции исходя из исторических условий реципиента, а также структуралистскую идею рецепции как культурного диалога прошлого и настоящего.

Сегодня основное направление рецепции античности включает в себя классическую традицию, интеллектуальную историю, сравнительное литературоведение, философские и исторические дискуссии, феминистскую модель рецепции, рецепцию античности в современном искусстве. Такой всеобъемлющий подход к классике позволяет называть исследования рецепции культурологическими.

Как бы индивидуально ни было восприятие античного произведения, к эмоциональному переживанию реципиента прибавляется «реципионная установка» [5, с. 15], сформированная в сознании человека всем его предыдущим социокультурным опытом. Иными словами, у реципиента античности имеется собственное, уникальное представление о данной эпохе, которое наряду с социокультурной действительностью реципиента определяет его рецептивную эстетику. Многофакторность такого процесса выводит понятие рецепции в междисциплинарное поле гуманитарного знания. Рецепция античности становится предметом исследования искусствоведческих, филологических, философских, психологических, социальных наук, а также наук о коммуникации. 
Современная рецепция античности имеет особые черты благодаря появлению так называемой «массовой культуры». Как отмечает культуролог М. Найдорф, современностью может считаться «переживаемый нами период времени, когда наибольшим влиянием в мире пользуются массовые цивилизации/культуры» [10, с. 7]. В условиях массовой культуры любое обращение к античности приобретает общественно значимый характер, увеличиваются возможности для интерпретации античного материала $[11$, с. 65]. Журналисты, художники и писатели свободно интерпретируют имеющиеся исторические данные, художественные произведения и античную мифологию, домысливают то, что необходимо им для реализации творческих замыслов.

В европейской культуре античность присутствует в общественном сознании в форме социокультурной памяти, представляющей собой совокупность научных и вненаучных знаний, массовых представлений о прошлом. Для всех обществ европейской культурной традиции античность является фундаментом цивилизации, поэтому для изучения рецепции античности необходимо принимать во внимание социокультурную память реципиентов, в том числе характерную для «массового сознания».

В общественном сознании античность представляет собой символическую реальность, каждый исторический или мифологический персонаж становится символом понятного современному человеку качества или деятельности. Социокультурная память, таким образом, становится «символической репрезентацией» [5, с. 25] памяти о прошлом. Художник или писатель в своей интерпретации античного сюжета может акцентировать внимание на том качестве персонажа или подробностях его жизни, которые символически выражает проблемы или потребности современного общества.

В культурологической традиции античность рассматривается как особый тип культуры [12, с. 218]. Чтобы понять, чем именно характеризуется античная культура, что она символизирует собой для современного человека, можно обратиться к известному историку и культурологу Г.С. Кнабе, который исследует античное наследие. Г.С. Кнабе выделяет три основных черты античной культуры: героическая норма (патриотизм, принесение себя в жертву родине), классика (равновесие личности и общества, нормы и жизненной практики) и эстетическая норма (форма как подлинное бытие, упорядочивание хаоса, обретение организованной формы эмпирической действительностью) [13, с.11-12]. Эти черты как античные достижения, являющиеся символом античной культуры, имеют всемирноисторическое значение, поскольку они определили важнейшие пути развития западной цивилизации. Согласно Г.С. Кнабе основные цивилизационные характеристики и принципы политического устройства (демократия, свобода в рамках законодательства, равенство перед законом, разделение властей, феномен гражданской ответственности) и основные ценности (рациональное мышление, культура и наука, направленные на преобразование действительности) имеют античное происхождение [13, с. 12]. Понимание античной культуры при этом восходит к понятию системы ценностей, поэтому в качестве объекта рецепции могут стать самые разные явления, присущие античной эпохе, а рецепция античности выступает как диалог культур, происходящий вне временных границ.

Культурный диалог античности и современности представляет собой коммуникацию, которая одновременно сохраняет смысл интересующих современность образов античности и передает имеющуюся в них информацию. Такой диалог культур, разделенных временем, возможен в сознании реципиента, согласно идеям культурного диалога М.М. Бахтина и В.С. Библера. Духовные центры различных этапов развития европейской культуры соединены в сознании исследователя в одной точке, и ни один из них не может быть понять без учета остальных. В.С. Библер, опиравшийся на концепцию диалога Бахтина, подчеркивает, что культура способна развиваться только в непрерывном диалоге с другими целостными культурами.

Согласно концепции В.С. Библера, в искусстве нет восхождения знания (в отличие от науки, где происходит наращивание интеллектуального «продукта» путем развития предшествующих идей в форме научных открытий), каждое последующее во времени 
произведение искусства не является усовершенствованием предыдущего. Для постижения искусства не только не достаточно изучения современного искусства, но необходимо изучать искусство иных эпох. Кроме того, В.С. Библер утверждает, что появления каждого нового произведения искусства усложняет процесс понимания предшествующих произведений, поскольку адресует им новые вопросы и одновременно отвечает по-новому на вопросы, поставленные предшественниками.

Таким образом, В.С. Библер подчеркивает, что ни один автор не может быть понят без осмысления его трудов в связи с трудами других авторов. Не только древность формирует современность, а ее произведения существуют благодаря наработкам древних авторов (в нашем случае античных), но верно и обратное - современность и ее произведения (в том числе интерпретации античных сюжетов) позволяют переосмыслить античность как эпоху, приблизиться к пониманию ее культурных основ, осознать глубже ее проблематику и ключевые вопросы [14, с. 31-42].

С одной стороны, античность удалена и с каждым годом все более удаляется от современности, и, несмотря на сохранившиеся артефакты, культурно мы меняемся, претерпевает изменения и наша система ценностей, поэтому нам трудно понять античную эпоху, «внедрить» свою личность в пространство иной, не ведомой нами на опыте культуры. С другой стороны, такой разрыв во времени и опыте позволяет нам исследовать античный мир на интуитивно-эстетическом уровне, в пространстве искусства. Современные авторы пишут с позиции понятной нам реальности, обладают близким нам социокультурным опытом. Они как бы переводят непонятный нам язык далекой, идеализированной и ставшей почти мифической культуры на язык общей для нас реальности.

Кроме того, интерпретируя античные мифы (как предмет художественного освоения мира) современные авторы наделяют их новым пластом смыслов, представляя картину античного мифа во все большей многогранности. Таким образом, не только изучение античности проливает свет на особенности современной западной культуры, но и изучение современной ситуации в Европе помогает лучше понять своеобразие античной культуры. Субъект, обращающийся к взаимодействию с античной эпохой, снимает временные и пространственные границы своей культуры, древняя культура как бы «присутствует» в современных социокультурных условиях, а античность воздействует на современную реальность. Собственно понятие рецепции позволяет проследить особенности этого процесса и его результаты.

Освоение античного наследия становится попыткой адаптировать античную систему ценностей к современному обществу. Рецепция античности, ее фундаментальных норм и идеалов становится особенно актуальной в эпоху быстро меняющейся, неустойчивой системы ценностей, поиска нравственных оснований и перехода к массовой культуре, свойственных XX-началу XXI вв. Рецепция античности используется как инструмент решения актуальных проблем современности. Обращение к высокой культуре прошлого помогает реципиентам найти путь к гармонии в условиях духовного кризиса.

$$
* * *
$$

1. Словарь Ушакова http://ushakovdictionary.ru/word.php?wordid=66359 (доступ 5.08.2021 г.)

2. Рецепция античности /Словарь Античности/ отв. ред. Кузищин В.И. - М.: Прогресс, 1989.

3. Новиков М.В., Перфилова Т.Б. В.П. Бузескул: принципы исторического исследования. // Ярославский педагогический вестник. - 2008, №1 (54). С. 48-56

4. Бузескул В.П. Античность и современность. - Л.: Наука и школа, 1924. 144 с.

5. Чиглинцев Е.А. Рецепция античности в культуре конца XIX-начала XXI вв. - Казань: Изд-во Казан. ун-та, 2009. -290 c.

6. Грабарь-Пассек М.Е. Античные сюжеты и формы в западноевропейской литературе. М.: Наука, 1966. - 320 с.

7. Фомин К.А. Концепция рецептивной эстетики Ханса Роберта Яусса как принцип конституирования и динамики литературной традиции // Вестник Томского государственного университета. Серия Философия. Социология. Политология. 2015, № 2 (30). С. 169-176.

8. Reception study: from literary theory to cultural studies/edited by James L. Machor and Philip Goldstein. - NY: Routledge, 2001. 412 p. 
9. Stam R. Literature through film: realism, magic, and the art of adaptation. - Malden: Blackwell Publishing, 2005. $388 \mathrm{p}$.

10. Найдорф М. Современность и массовая цивилизация// Вопросы культурологии. - 2010, № 2. С. 4-10

11. Шемякин Я.Г. Межцивилизационное взаимодействие и типы творческой личности // Латинская Америка. 1997, №4. C. 64-71.

12. Античность как тип культуры/А.Ф. Лосев, Н.А. Чистякова, Т.Ю. Бородай и др. - М.: Наука, 1988. - 336 с.

13. Кнабе Г.С. Русская античность. Содержание, роль и судьба античного наследия в культуре России. М.:РГГУ, 2000. 238 с.

14. Библер В.С. Культура. Диалог культур (Опыт определения)// Вопросы философии. - 1989, №6. С.31-42. 